\title{
Biotechnology of the sweetpotato: ensuring global food and nutrition security in the face of climate change
}

\author{
Sang-Soo Kwak ${ }^{1}$
}

Received: 27 August 2019 / Accepted: 28 August 2019 / Published online: 7 September 2019

c) Springer-Verlag GmbH Germany, part of Springer Nature 2019

A dramatic increase in global population combined with rapid industrialization in developing countries has placed great strain on the global food and energy supply. In addition, food security is threatened by global climate change, and with an aging population, maintaining an abundant supply of healthy foods presents an ever-increasing challenge. To my scientific knowledge, the sweetpotato [Ipomoea batatas (L.) Lam], a starch crop, has the ability to address these global problems and promote a sustainable society. In addition, the sweetpotato has been re-evaluated as a valuable medicinal plant with anticancer, antidiabetic, and anti-inflammatory properties. The review article and original research papers covered in this special issue describe the characteristics of the sweetpotato that indicate its potential to address the issues of food and nutrition security in the context of a changing global climate.

While progress is being made in eliminating global hunger and malnutrition, it is not sufficient to meet the goals of the 2030 Agenda for Sustainable Development (FAO 2018). According to estimates from the Food and Agriculture Organization of the United Nations (UN-FAO), the world population is likely to exceed 9.7 billion by 2050 . If we continue consuming energy and food at the present rates, our requirements in 2050 will exceed current needs by more than 3.5-fold and 1.7-fold, respectively. Climate change also increasingly limits our ability to feed the growing population. Agricultural production is extremely vulnerable to climate change; thus the potential effects of climate change have life-threatening implications for the global population. The aging society is another global issue, as an older population requires an abundant supply of healthy foods. To cope with the global crises of food, nutrition, and energy supply

Sang-Soo Kwak

sskwak@kribb.re.kr

1 Plant Systems Engineering Research Center, Korea Research Institute of Bioscience and Biotechnology (KRIBB), 125 Gwahak-ro, Daejeon 34141, South Korea and environmental changes, new eco-friendly industrial crop varieties are urgently needed to ensure a sustainable future. It is imperative that we pay attention to marginal lands such as semi-arid, high-salinity, and contaminated areas for sustainable agriculture. Plant biotechnology can be used as a tool to maximize plant productivity by introducing stress tolerance and metabolic genes in existing crop cultivars. The sweetpotato [Ipomoea batatas (L.) Lam] is a starch crop with high potential to meet the food and nutrition security needs for a sustainable society in the twenty-first century.

\section{Why sweetpotato biotechnology?}

The sweetpotato offers many advantages over other starch crops for addressing the problems of global food security and climate change. It has high water use efficiency, and it reduces soil erosion during the rainy season and can therefore be used as a cover crop. All parts of the sweetpotato plant, including leaves, stems, and tuberous roots, can be used for human and animal consumption. Because of its high nutritional content and wide adaptability to marginal lands in areas ranging from the tropics to temperate zones, the sweetpotato is a promising crop for preventing malnutrition and increasing food security in developing countries. At high latitudes, sweetpotato plants require less chemical pesticide and fertilizer treatment. The minimum requirement for sweetpotato cultivation is a frost-free period lasting at least 4 months. We have successfully cultivated sweetpotatoes on marginal lands and areas of desertification at high latitudes in the Northern Hemisphere (Kim et al. 2018). Moreover, the US National Aeronautics and Space Administration (NASA) has selected the sweetpotato as one of the primary food sources in a controlled ecological life-support system because of its high nutritional content (Hoff et al. 1982). According to the United States Department of Agriculture (USDA), sweetpotatoes have higher carbohydrate content than other starch crops, suggesting their potential for 
bioethanol production on marginal lands (Ziska et al. 2009). The nonprofit Center for Science in the Public Interest (CSPI 2007) describes the sweetpotato as one of ten superfoods for better health, as it contains high levels of low molecular weight antioxidants such as carotenoids and vitamin $\mathrm{C}$, as well as dietary fiber and potassium. The sweetpotato was recently re-evaluated as a valuable medicinal plant, with anticancer, antidiabetic, and anti-inflammatory properties (Mohanraj and Sivasankar 2014; Wang et al. 2016).

In this special issue, a review article describes the current status in whole genome sequencing and analysis of Ipomoea spp. for molecular breeding of sweetpotatoes (Isobe et al. 2019). Original research articles covered in this special issue focus on various areas of abiotic and biotic stresses, and the production of carotenoid and protein in transgenic sweetpotatoes ranging from functional genomics to transgenic plant systems. Two papers describe enhanced tolerance to abiotic stresses, including a novel sweetpotato bZIP transcription factor IbbZIP in Arabidopsis that confers salt and drought stress tolerance (Kang et al. 2019), and co-expression of Arabidopsis $\mathrm{Na}^{+} / \mathrm{H}^{+}$antiporter $\mathrm{NHXI}$ and DEAD-box RNA helicase IF $4 A 1$ in sweetpotatoes with enhanced tolerance to drought stress (Zhang et al. 2019). Three papers describe biotic stress tolerance. Okada et al. (2019) applied genomewide association studies of sweetpotato to identify the single-nucleotide polymorphisms (SNPs) associated with yield and resistance to weevil, the most serious insect pest in sweetpotato. Kim et al. (2019a, b) found that phosphorylation of IbSPF1 by IbMPK3/IbMPK6 played a critical role in sweetpotato plant immunity. Zhong et al. (2019) generated a transgenic sweetpotato over-expressing a CrylAa gene with improved insect resistance against Spodoptera litura. Kim et al. (2019b) demonstrated that a single amino acid substitution at position 96 (IbOrR96H) of orange protein involved in the regulation of carotenoid accumulation and abiotic stress tolerance resulted in overaccumulation of carotenoids in transgenic sweetpotato calli. Honma and Yamakawa (2019) investigated the high expression of $\beta$-glucuronidase (GUS) in the storage roots of sweetpotatoes by sucrose-inducible minimal promoter for the possible production of useful materials in the sweetpotato.

\section{Perspectives}

The sweetpotato has long been considered a staple food crop for poor populations in developing countries. Recently, however, the sweetpotato has garnered interest among relatively wealthy populations as one of the best health foods based on scientific evaluation. European countries imported 244,000 tons of sweetpotatoes in 2017, compared with 96,000 tons in 2013, indicating a rapid increase in sweetpotato consumption in developed countries (CBI 2019). The price of sweetpotatoes is much higher than that of potatoes and other starch crops because of its high nutrient content and diverse biological properties. I strongly believe that the sweetpotato will receive more attention than other crops as a means of addressing the global problems of food, energy, health, and environmental security.

Because the sweetpotato is a global asset, international collaborations among researchers in the field are extremely important, as collaborative projects will help to find solutions to the above-mentioned global issues. The biennial sweetpotato symposium is organized by the Trilateral Research Association of Sweetpotato (TRAS), established in September 2012 between China, Japan, and Korea. The ninth International Sweetpotato Symposium will be held at Xuzhou Sweetpotato Institute, China, in 2020. Isobe et al. (2019) describe the current status of sweetpotato genome sequencing on the basis of TRAS sweetpotato whole genome sequencing data. Here, I propose a molecular breeding strategy for the development of new sweetpotato cultivars suitable for cultivation on marginal lands to promote a sustainable society. The sweetpotato produces relatively good yields on marginal lands. We can maximize the productivity of sweetpotato plants by introducing genes that improve biotic and abiotic stress tolerance levels and enhance metabolic pathways. This will lead to the production of value-added products such as functional food, antioxidants, and edible vaccines in all tissues of engineered sweetpotato cultivars as a blue ocean strategy.

Acknowledgements I sincerely wish to thank all the contributors and the people in the Editorial office of the journal for their help, which made it possible to publish this special issue. This work was supported by grants from the National Research Foundation of Korea (NRF) funded by the Korean Government (2018R1A2A1A05077883).

\section{References}

CBI (2019) Exporting fresh sweet potatoes to Europe. https://www. cbi.eu/market-information/fresh-fruit-vegetables/sweet-potatoes

CSPI (2007) Ten best foods for better health. Retrieved from http:// www.nutritionaction.com/get-download/download/?dtd=16511 $\& \mathrm{n}=1$

FAO (2018) The future of food and agriculture: alternative pathways to 2050. Food and Agriculture Organization of the United Nations, Rome. http://www.fao.org/global-perspectivesstudies/resources/ detail/en/c/1157074/

Hoff JE, Howe JM, Mitchell CA (1982) Nutritional and cultural aspects of plant species selection for a controlled ecological life support system. NASA Contractor Rep. 166324. Moffett Field, Cali. National Aeronautics and Space Administration, USA

Honma Y, Yamakawa T (2019) High expression of GUS activities in sweetpotato storage roots by sucrose-inducible minimal promoter. Plant Cell Rep. https://doi.org/10.1007/s00299-019-02453-7

Isobe S, Shirasawa K, Hirakawa H (2019) Current status in whole genome sequencing and analysis of Ipomoea spp. Plant Cell Rep. https://doi.org/10.1007/s00299-019-02464-4 
Kang C, Zhai H, Shaozhen He, Zhao N, Liu Q (2019) A novel sweetpotato bZIP transcription factor gene, IbbZIPI, is involved in salt and drought tolerance in transgenic Arabidopsis. Plant Cell Rep. https://doi.org/10.1007/s00299-019-02441-x

Kim HS, Lee CJ, Kim SE, Ji CY, Kim ST, Kim JS, Kim SY, Kwak SS (2018) Current status on global sweetpotato cultivation and its prior tasks of mass production. J Plant Biotechnol 45:190-195

Kim HS, Bian X, Lee CJ, Lim SE, Park SC, Xie Y, Guo X, Kwak SS (2019a) IbMPK3/IbMPK6-mediated ibSPF1 phosphorylation promotes tolerance to bacterial pathogen in sweetpotato. Plant Cell Rep. https://doi.org/10.1007/s00299-019-02451-9

Kim SE, Kim HS, Wang Z, Ke Q, Lee CJ, Park SU, Lim YH, Park WS, Ahn MJ, Kwak SS (2019b) A single amino acid change at positions 96 (Arg to His) of the sweetpotato Orange protein leads to carotenoid overaccumulation. Plant Cell Rep. https://doi. org/10.1007/s00299-019-02448-4

Mohanraj R, Sivasankar S (2014) Sweet potato (Ipomoea batatas (L.) Lam) — a valuable medicinal food: a review. J Med Food 17:733-741

Okada Y, Monden Y, Nokihara K, Shirasawa K, Isobe S, Tahara M (2019) Genome-wide association studies (GWAS) for yield and weevil resistance in sweetpotato (Ipomoea batatas (L.) Lam). Plant Cell Rep. https://doi.org/10.1007/s00299-019-02445-7
Wang S, Nie S, Zhu F (2016) Chemical constituents and health effects of sweet potato. Food Res Int 89:90-116

Zhang Y, Deng G, Fan W, Yuan L, Wang H, Zhang P (2019) NHXI and elF4Al-stacked transgenic sweetpotato shows enhanced tolerance to drought stress. Plant Cell Rep. https://doi.org/10.1007/s0029 9-019-02454-6

Zhong Y, Ahmed S, Deng G, Fan W, Zhang P, Wang H (2019) Improved insect resistance against Spodoptera litura in transgenic sweetpotato by overexpressing Cry1Aa toxin. Plant Cell Rep. https://doi.org/10.1007/s00299-019-02460-8

Ziska LH, Runion GB, Tomecek M, Prior SA, Torbet HA, Sicher R (2009) An evaluation of cassava, sweetpotato and field corn as potential carbohydrate sources for bioethanol production in Alabama and Maryland. Biomass Bioenerg 33:1503

Publisher's Note Springer Nature remains neutral with regard to jurisdictional claims in published maps and institutional affiliations. 